\title{
Innovation Management of Organic Waste into Methane in Landfill Gampong Java Banda Aceh
}

\author{
Taufik $^{1}$, Retno Sunu Astuti ${ }^{2}$ \\ \{taufik.fisip@ar-raniry.ac.id ${ }^{1}$, retnosunu@gmail.com ${ }^{2}$ \} \\ Universitas Diponegoro, Indonesia ${ }^{1,2}$
}

\begin{abstract}
The increase in the volume of waste to be one of the problems commonly faced by the region in Indonesia, one of which is the city of Banda Aceh. Based on data from the Department of Environmental Cleanliness and Beauty of the city of Banda Aceh (DLHK3), the amount of waste produced by the city of Banda Aceh as much as 200 tons per day. Thus, we need innovation in waste management. This study aims to identify the level of innovation and analyze the impact of innovation. This study used a qualitative approach, data collection by way of interviews and documentation in the form of reports, journals and articles that are relevant to the study. The results showed that innovation Gampong landfill biogas in Banda Aceh Java can be considered independent innovation. Because innovation biogas produced on the ideas and concepts of DLKH3, instead of the results of the visit or study of other areas. Before and after the impact of an increase in the number of biogas innovation every year recipient landfill biogas distribution of Java Gampong Banda Aceh. Then, decrease in expenses for LPG gas needs by the community before and after the biogas innovation. Therefore, biogas innovation should be continued and expanded into other new energy sources that can be utilized by the community.
\end{abstract}

Keywords: Innovation, Waste, Biogas.

\section{Introduction}

Innovation in the public sector becomes a necessity for the government, in line with the demands of the times and technology requiring the government to respond to the various needs of the community. The spirit of innovation in the study of public administration embodied in the concept of New Public Management and Reinventing Government. This movement is one of the driving force in improving the performance of government and public services [1][2], Farazmand argued that without innovative and adaptive administrative or managerial system, innovative policies are doomed to failure [3], It is claimed that innovation to be important to the improvement of government performance.

Innovation is believed to help the government in solving the problems. As the results of research conducted by Tahir and Harakan that the product innovation smart card in Makassar very helpful in accessing any public facility, be it education, health, transportation, economic, bureaucratic, and other facilities [4].

Innovation is not only related to the public service, but innovation can also be a program or policy. One is the innovation of waste management. Trash becomes a big problem in line with the increase of population. If not optimally managed, it will cause ecological problems. In response, the government has issued a policy on waste management as stipulated in Law 
No. 18 of 2008 and Presidential Decree No. 972017 about policy and national waste management strategy. Through the policy issued October 23, 2017, the government targets to reduce waste by $30 \%$ in 2025 .

Waste problem also experienced by Malaysia, an increase of 19,100 tons of waste per day in 2005 to 30,000 tons per day in 2020. Waste management with solid waste management is recycling bins[5], Therefore it takes a special strategy for waste management, because the garbage productivities is increasing every day.

Banda Aceh is one of the city's population growth and increasing urbanization. Based on data from the Central Statistics Agency (BPS), the number of residents of Banda Aceh in the year 2017 reached 259913 inhabitants. Shows the speed of population growth in the city of Banda Aceh increased by 1.96 percent from the previous year[6], This will certainly have an impact on the increase in produce bins. In one day, the amount of garbage in Banda Aceh reached 200 tons. The volume of waste continues to grow from year to year. Up to 2018 garbage disposal site (TPA) Gampong Java reaches a height of 33 meters above sea level [7].

Heaps of garbage is actually used by the City of Banda Aceh for fuel produced from the methane gas called biogas. Biogas Innovation was created first of all by the year 2015. This work delivers Banda Aceh ranked the Top 40 Information Openness Public Service Innovation in 2017. In the same year this innovation in the category of top 99 public service innovation Kemenpan version RB.

From 2015 the number of household's beneficiaries of biogas is constantly increasing. In the first year of biogas assistance provided to 25 households, the next in 2016 was given to 27 households, and in 2017 was given to 60 households. Until 2018 the biogas assistance has been given to 175 households. The presence of this biogas helps the community in domestic gas needs. This paper will discuss the level of innovation in the management of the waste into gas and analyze the impact of innovation in landfill biogas Java Gampong Banda Aceh.

\section{Theoretical Framework}

\subsection{Concepts and Innovation Type}

Defining innovation in the public sector is not synonymous with innovation in the private sector. Innovation is not just about something new, but also provide added value, either in the process or output of a product or service/goods produced. Therefore, a simple definition of public sector innovation is all about new ideas that work to create public value [8].

Government regulation 38 of 2017 on regional innovation states that innovation area are all forms of innovation in the delivery of Local Government which aims to improve the performance of government administration. On the other hand, innovation can defined as a necessary condition for government modernization to meet new challenges [9]. Joseph Schumpeter (1942), defined innovation as a process of creative destruction in the which 'new combinations of existing resources' are Achieved. Innovations categorizing Several attempts have been made in the literature to classify innovations [10].

Innovation can be understood as a new discovery or development of a product that is a long time to help the performance of the government. This innovation is based on creativity appears to be possessed. Thus, with no expected innovation performance of governments can be improved for the better. 
Based on the research literature, at least there are the types of innovation [11][12][10][13][9], among others:

a) Innovation services or products, which focuses on the creation of new public services or products (goods/services).

b) Technological innovations that arise due to the creation and use of new technologies, such as the use of SMS device to alert the public in case of disaster.

c) Innovation process, innovation is focused on increasing the quality and efficiency of public services.

d) Innovation management and organization, innovation focuses on the creation of new organizational forms, the introduction of new management methods and techniques, as well as new work methods.

e) Conceptual innovation, innovation is happening in relation to the introduction of new concepts, frames of reference, or even a new paradigm that helps provide solutions to problem solving.

f) Innovation governance, innovation is focused on the development and governance processes form a new government, such as capacity building and policy networks.

g) Institutional innovation, innovation focuses on a fundamental transformation in the institutional relationship between organizations.

These kinds of innovations are correlated with each other. For example, the development of technological innovation allows the government to redesign the process of providing information and services to the public. Meanwhile, another expert arguments there are three levels of innovation [14], that is:

a) Adoptive Innovation. Namely innovation which is based on programs that already existed and considered successful by the local government. Innovation was later imitated fully or partially from the program with the same program name or a new name. The difference after applied elsewhere is in terms of resources and the allocation of funding and responsible activity. For previous programs deemed successful will be followed by the community participation.

b) Instructive Innovation. Namely the local government innovation that comes from the President's instruction (PI), a Presidential Decree (Presidential), Decree (Decree), and so on, which in principle come from the central government policy. Such programs are usually implemented based on the technical guidelines or standard operational guidelines that made the Central Government to be implemented in these areas. Claims for the success achieved on the program that is instructive not one to be made public.

c) Independent Innovation. Independent innovation is the innovative breakthroughs of local government on the basis of need, namely the need to resolve the problems that exist in society. The resulting innovations adapted to the existing environmental conditions and capabilities. An example is when people in remote areas find it difficult to seek treatment due to accessibility and transportation facilities are still minimal, then the local government is trying to make a breakthrough by sending medics to go into these areas.

\subsection{Impact evaluation}

The impact can be understood as an outcome of the result or the effect of a government policy or program relating to the results expected in unexpected happens. The impact can be either positive or negative, as well as a direct or indirect impact.

There are six impact evaluation approaches that can be used to measure the level of success of the implementation of the program [15], that is: 
a) Before and after comparisons

That compares approach (people or residents of an area) and after the program. In addition, this approach can also be used to compare the condition of the people after the program starts.

b) With and without comparisons

The approach is to compare between the target group receiving the program and who is not. The difference with the above approach is the need for the selection of the group will be compared with the right.

c) Actual performance versus planed comparisons

This approach compares data on actual post-implementation of the program on program objectives arising from the previous time period. Analysts determine the specific goals and targets to make the evaluation criteria before the programs are implemented in order to determine the time period of the program.

d) Experimental (controlled) models

This approach uses the concept of equivalent control and tested groups as well as measures of pre- and post-implementation of the program. The unit of analysis is the individual in a randomly selected group.

e) Quasi-experimental models

This approach attempts to measure the results of programs or policies through the score, numbers or other indicators. This approach also tries to maintain the logic of the experiment without the use of a procedure, or other techniques.

f) Cost oriented approaches

This approach is a response to conditions requiring measures the impact of policies in terms of money. Estimates of cost and net gains and net gain from changes detect of the implementation of the program.

\section{Research Methods}

This study used a qualitative approach with data collection techniques such as interviews and documentation in the form of reports, journals, articles and other relevant documents. Data analysis using techniques Miles and Huberman consisting of the reduction, data presentation, and conclusion and data verification [16].

\section{Result and Discussion}

\subsection{Biogas Innovation in Java Gampong City Banda Aceh}

TPA Gampong first Java once built in 1994 with an area of 12 hectares. Waste management system is done in open dumping (open exhaust systems) that is rubbish just dumped in the landfill and left open without any processing. These systems generate a lot of negative impact on the environment around the landfill such as pollution of water, soil, air, unpleasant odors, garbage strewn, and become a den of germs. When the earthquake and tsunami of 2004, the landfill Gampong Java were destroyed and swept all the trash that was there. However, when the height of the waste is not too high compared to the waste landfill today. 


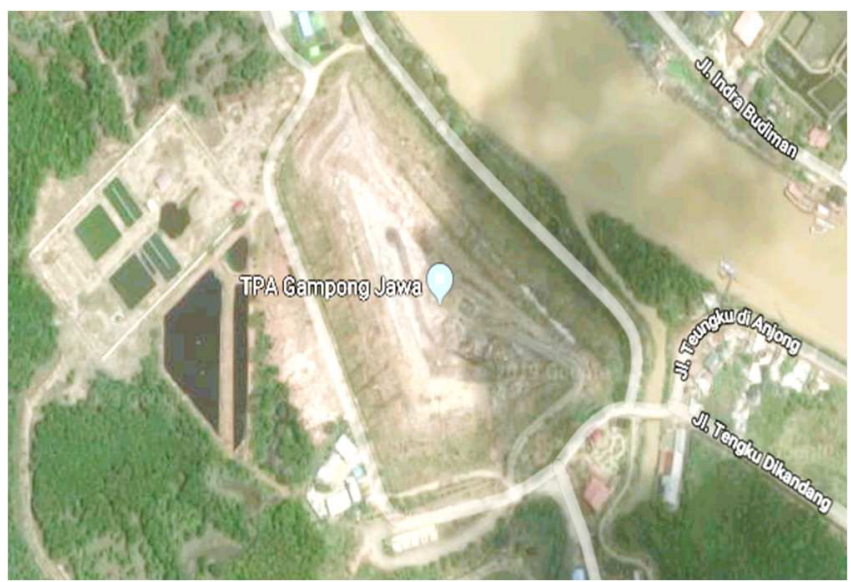

Fig. 1. Map Location Gampong Java (Google Map, 2019).

After the tsunami, Java Gampong landfill functioned and was expanded to 21 hectares. In 2008, the landfill was rehabilitated by the Rehabilitation and Reconstruction Agency (BRR) Aceh-Nias. In the beginning of the redevelopment of the landfill does starting from the basic foundation of the landfill as a tarp, then the process of formation and installation of water distribution pipes leachate (waste fluids).

Waste management innovations into biogas in the Village of Java is already running in period of 4 (four) years, from 2015 until now. These innovations get a positive response from the community. Because people can feel the direct benefits.

This innovation concerns motivated the government to increase the volume of waste in the city of Banda Aceh. Currently the waste in the landfill Banda Aceh reached a height of 33 meters above sea level. Piles of garbage is in principle the gas containing methane, if not used then at any time there will be explosions and landslides.

Landfill biogas innovation in Banda Aceh categorized as independent innovation. As noted by Hutauruk, that independent innovation is a breakthrough innovation that local governments on the basis of needs. Requirement in question is the need to resolve the problems that exist in society.

These innovations early emergence of the idea of staff at the Department of Environment, Cleanliness and beauty of the city of Banda Aceh (DLHK3), trying to manage the waste into biogas. This innovative idea was later developed into biogas with the cooperation of NGOs and academics utilize waste into gas. So, innovation landfill biogas in Banda Aceh instead of a result of the adoption of other places, such as the comparative study, but this innovation is born independent.

Management of organic waste into methane gas as alternative gas (biogas) are performed in the technique and based on the Standard Operating Procedure (SOP). Methane gas capture system is carried out through a pipeline which has two positions namely vertical and horizontal pipe that serves as an absorber of methane contained in landfill (landfill land).

Biogas is provided free of charge by the government to the poor people who live in the Village of Java and Gampong Pande located around the landfill. Biogas is streamed home through pipelines installation 1 inch (parent) which is driven by the engine compressor. Communities can use the biogas is only on a predetermined schedule which is 08.00 till 12.00 and 15.00 till $18.00 \mathrm{pm}$. Because of the time it was considered a productive time for cooking. 
Therefore, the purpose of the innovation management of organic waste into methane gas by using energy utilization systems (waste to energy) to solve the problems of landfill waste and reduce the volume of landfill waste at the landfill Gampong Java, Banda Aceh. And make the waste as a resource by utilizing methane gas into the pile of organic waste as an alternative gas (biogas) that can be utilized by the community.

\subsection{Biogas Innovation Impact Analysis in Java Gampong Banda Aceh}

Each program or government policies have an impact on the recipient policies or referred to as a target group. Thus, we can determine whether the policy is a positive influence or already answered the problems faced by the community.

In this study, the approach to analyze the impact of innovation using an approach Before and after comparisons. Approach that sees comparisons compare the before and after government programs implemented. This approach can also be used to compare the condition of the people after the program starts.

Before the advent of this biogas innovation, increase the volume of waste becomes a major problem for the Department of Environment, Cleanliness and Beauty of the city of Banda Aceh. Because the garbage heap on the one hand have an impact on environmental pollution, on the other hand have an impact on disease spread from the trash. Thus, proper management is required so that the waste can be a source of renewable energy.

Since innovation of biogas was implemented in 2015, much of the impact felt by the community. Especially the distribution of biogas is constantly increasing the number of recipients. The following data on the number of biogas in a vulnerable distribution recipient of four years (2015-2019) as follows:

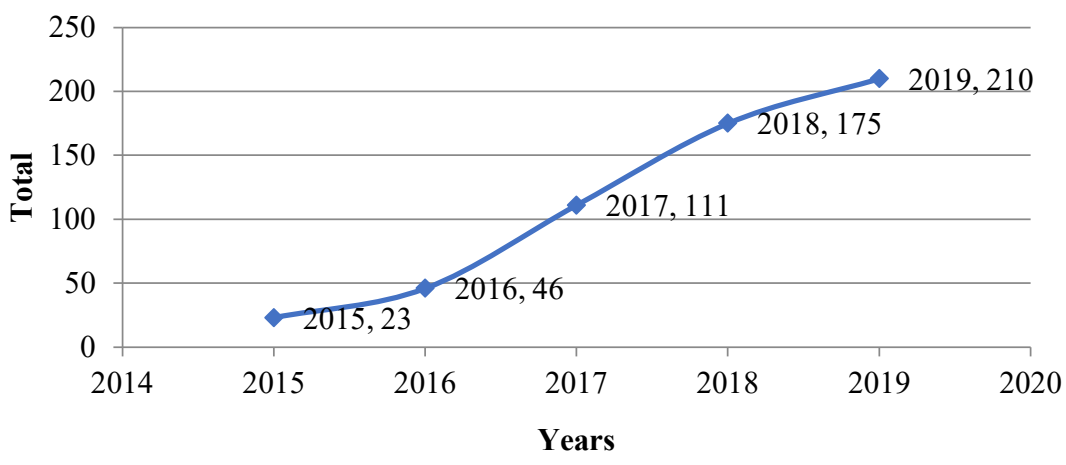

Fig. 2. Number of recipients Biogas years 2015-2019 (DLHK3 City of Banda Aceh, 2019).

Based on the above table, showed an increase in the number of recipients of biogas from year to year. There are several categories of recipients of biogas Gampong Java city of Banda Aceh, namely:

a) Poor, poor criteria based on income per capita visits by village standards or poor people who never get help from the village.

b) People who own their own home, meaning that people are the rightful owner-occupied homes and not as tenants. 
c) People who have a small business, such as business pie, meatball business and other small businesses. This is done to help the community's economy. At least people no longer buy gas for cooking.

In addition to increasing the number of beneficiaries of biogas, other impact is the cost savings incurred by the community for the fulfillment of gas in the house. This biogas innovation help people who should be able to pay to buy LPG gas, which on average spend one month two gas cylinders as Rp.70.000, -. So, you can save on the cost of household expenditure on gas fulfillment. However, after the existence of biogas, the cost of public expenditure towards the fulfillment of gas has decreased. This is according to the data below:

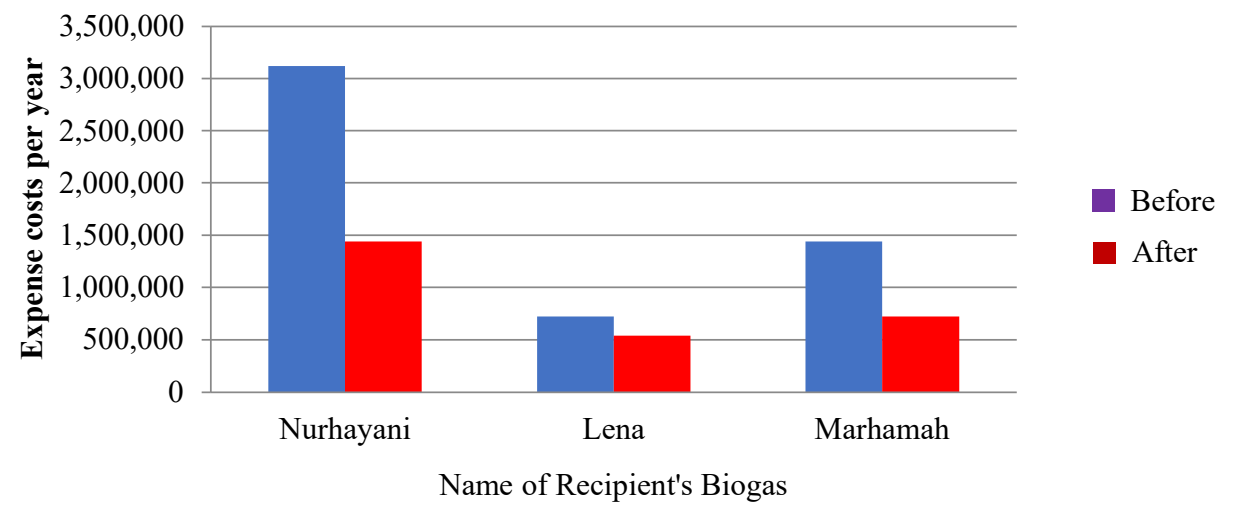

Fig. 3. Public Expenditure Cost per Year Before/After existence of Biogas [17].

Based on the above graph shows a decrease in public expenditure costs against LPG gas before and after the biogas innovation in Java Gampong Banda Aceh. That is, this biogas innovation positive impact on the surrounding community. Thus, the impact felt by society towards more biogas innovation in economic impact. The community itself has been saving to finance expenditure needs of gas annually.

\section{Conclusion}

Innovation is a must for local governments in addressing social problems, including the one of which is the problem of waste. Innovation biogas Java village of Banda Aceh can be categorized as independent innovation. Innovations are born of ideas and concepts, not the result of special studies or comparative studies in other areas. Banda Aceh city government concerns over the increase in the volume of waste has resulted in innovative biogas. Thus, the energy produced by waste into biogas can be used by the public for household needs.

Based on data obtained from DLHK3 Banda Aceh, the impact on the amount of the distribution of biogas, which each year continues to increase. On the other hand, the impact is felt before and after the biogas is cost reduction of the fuel needs of the domestic gas needs. Therefore, this biogas innovation should be continued and further developed into a new energy that can be utilized by the public. 


\section{References}

[1] J. Wu, L. Ma, and Y. Yang, "Innovation in The Chines Public Sector: Typology and Distribution," no. Kelman 2008, 2012.

[2] D. Osborne and and G. T, Reinventing Government: How the Entrepreneurial Spirits is Transforming the Public Sector. Addison-Wesley: Reading, MA, 1992.

[3] A. Farazmand, Sound governance: 2004.

[4] M. M. Tahir and U. M. Makassar, "Inovasi Pemerintah Daerah Dalam Pelaksanaan Program Smart Card di Kota Makassar," Pros. Semin. Nas. Prodi Ilmu Pemerintah. FISIP Unikom, no. December 2015, 2016.

[5] A. N. Eeda, "Solid Waste Management in Shah Alam City Residental Area," J. Sustain. Sci. Manag., vol. 13, no. 1, pp. 211-227, 2018.

[6] BPS, "Banda Aceh Municipality in Figures 2018," 2018.

[7] "Inovasi Biogas TPA Gampong Jawa." .

[8] OECD, Evaluation Feddback for Effective Learning and Accountability. OECD Publications Service, 2001.

[9] V. Bekkers, Innovation in The Public Sector Linking Capacity and Leadership. London: Cabinet Office, 2011.

[10] Schumpeter J A, Capitalism, Socialism, and Democracy. New York: Harper, 1942.

[11] Mulgan G and D. Albury, Innovation in the Public Sector. Prime Minister Strategy Unit. London: Cabinet Office, 2003.

[12] J. Hartley and J. Hartley, "Innovation in Governance and Public Services: Past and Present Innovation in Governance and Public Services : Past and Present," no. September, 2016.

[13] Putra Heru Syah, "Innovation in government: barriers and strategies 1 mendorong inovasi di pemerintah: hambatan dan strategi," no. September, 2017.

[14] H. T. R, "Tinjauan Daya Inovasi Pemerintah Daerah Dalam Pelaksanaan Desentralisasi di Kabupaten/Kota Provinsi Kalimantan Timur," vol. Vol. 6 No., 2010.

[15] P. M, Utilization-focused evaluation, 4th edn. Sage Publication, 2008.

[16] Sugiyono, Metode Penelitian Kombinasi (Mixed Methods). Bandung: Alfabeta, 2013.

[17] W. Sofia, "Analisis Dampak Inovasi Pengelolaan Sampah Organik MenjadiGas Metana di TPA Gampong Jawa Kota Banda Aceh,” UIN Ar-Raniry Banda Aceh, 2019. 